\title{
GCU
}

Glasgow Caledonian

University

University for the Common Good

\section{How can universities contribute to the common good?}

MacFarlane, Karen

Published in:

Perspectives: Policy and Practice in Higher Education

DOI:

10.1080/13603108.2019.1567615

Publication date:

2019

Document Version

Author accepted manuscript

Link to publication in ResearchOnline

Citation for published version (Harvard):

MacFarlane, K 2019, 'How can universities contribute to the common good?', Perspectives: Policy and Practice in Higher Education, vol. 23, no. 4, pp. 122-131. https://doi.org/10.1080/13603108.2019.1567615

\section{General rights}

Copyright and moral rights for the publications made accessible in the public portal are retained by the authors and/or other copyright owners and it is a condition of accessing publications that users recognise and abide by the legal requirements associated with these rights.

Take down policy

If you believe that this document breaches copyright please view our takedown policy at https://edshare.gcu.ac.uk/id/eprint/5179 for details of how to contact us. 


\title{
How can universities contribute to the Common Good?
}

\begin{abstract}
The U.K. higher education system has become increasingly competitive and stratified prompting calls for a reclaiming of the civic role of universities. This paper argues that, if $\mathrm{HE}$ is to reclaim its civic function then civic engagement needs to move beyond being a separate strand of activity for universities, instead becoming a guiding principle. This requires an institution-wide commitment. The paper describes a model developed by a Scottish university to support, recognise and embed civic engagement within the curriculum and wider student experience as part of its core mission. The design and delivery of this development are described and early indicators of its efficacy are provided. Findings indicate that it is possible for universities to operationalise a civic mission by focusing on the curriculum as the mechanism through which to highlight and embed common good attributes. The model described could be replicated in other higher education institutions nationally and internationally.
\end{abstract}

Keywords: higher education; civic engagement; common good 


\section{Introduction}

The principle of higher education as a common good is underlined in Goal 4 of the United Nations Agenda for Sustainable Development, which aims to, 'ensure inclusive and equitable quality education and promote lifelong learning opportunities for all' (UNESCO, 2015). Thus, universities internationally bear a profound, moral and social responsibility to encourage an institutional culture of civic engagement. In many Higher Education (HE) institutions, however, the approach to encouraging a culture of civic responsibility lies within a specific unit or resource which can, in some cases, lead to this becoming an isolated activity (Musil, 2003). As the University for the Common Good, what differentiates Glasgow Caledonian University (GCU) is that civic responsibility is demonstrated through its mission and provided by its curriculum.

GCU has developed a model to support, recognise and embed the common good within the curriculum and wider student experience as part of its core mission, the goal of which is to ensure that students develop the attributes needed to make a positive difference to the communities they serve. That is, in addition to the knowledge, skills and values associated with their particular professional or disciplinary areas. The term 'curriculum' in this sense refers to the totality of the student learning experience, both formally within the taught curriculum and informally through co- and extra-curricular activities. The learning experience at GCU aims to prepare students to develop and implement new strategies and ideas that address societal challenges and needs, whether on a local, national or global scale. A key feature of this innovative model is that all programmes that are developed or reviewed are now required to embed the Common Good Attributes at all levels. These attributes are underpinned by the GCU core values of Integrity, Creativity, Responsibility and Confidence. 
This paper describes the design and delivery of this development and provides early indicators of its efficacy. The paper begins by locating the research question within the context of literature on Higher Education and the common good. An overview of the study's methodological approach follows. Findings are discussed in terms of the benefits to universities of operationalising a civic mission by focusing on the curriculum as the mechanism through which to embed common good attributes. Limitations of the study's evidence thus far are acknowledged before a conclusion is offered in terms of the theoretical contribution of the paper. The study addressed the following research question:

\section{Research Question:}

How can universities design and deliver a Common Good Curriculum?

\section{Higher education and the common good}

The concept of the common good is not a new idea. Indeed, its roots can be traced to Adam Smith who, in 1759, first described the harmony between personal and societal good in his theory of moral sentiments (Smith, 1759). The notion of HE's contribution to the common good is all pervasive (Delanty, 2005). This is perhaps because universities have traditionally played a critical role in holding the state to account, an idea that can be traced back to Kant (1798). Indeed, in the U.K. the majority of universities are part-funded by the state and have a charter to deliver social and economic benefit to the communities they serve. More recently the public good of HE has been linked to the promotion of social justice through increasing social mobility. Yet, whether there is such a thing as the 'common' or 'public' good of higher education, and if so, what constitutes the public good, are highly contested issues. What is public and private in education is a political and social construct which changes over time as 
the economic and social context of HE changes (Carnoy \& Froumin et al, 2014). The lack of a clear definition does nothing to forward the discourse (Daviet, 2016) and those definitions that do exist are still evolving (Marginson, 2018). For the purposes of this paper, Locatelli's stance has been adopted; that is, that education should be considered as part of the domain of the public where transparent and participatory processes can take place. Higher education is therefore a public and common good because it not only serves as an economic tool for individual progress, but above all, it is a 'collective endeavour for the fulfilment of humanbeings and of their communities' (Locatelli, 2018).

Currently, there exists an increasingly competitive and stratified HE system in the U.K. where, while massification has expanded social inclusion, some authors argue that attempts to create equality of social opportunity have failed and universities' contribution to the common good is being eroded (Dill, 2015, Marginson, 2016). A similar story is emerging from other parts of the world in that promotion of the concept of the public good in HE in the United States has declined over the past five decades (Reich, 2018). Leibowitz (2013) has charted a parallel decline in perceived relevance of the public good in South Africa. There has been an increasing concern over a perceived 'civic deficit,' particularly among young people in Australia over the same timeframe (Winter et al, 2006) leading Marginson (2016) to conclude that the 'Australian Government has a strong supervisory capacity in higher education and could advance the production of public goods if it was so inclined' (p. 263). Unfortunately, successive governments have adopted a neo-liberal policy that positions HEIs as, 'selfserving corporations, rather than public institutions' (Ibid.).

Successive attempts to redefine the common good are evident in the narrative of U.K. policy documents and demonstrate a shift in focus since the 1990s from knowledge as a public good in itself, to an emphasis on individual employability, increased earnings and job security. In 
other words, 'the public good has been redefined as the collective private gain' (Williams, 2014: 630). This has led to questions being asked as to how HE might contribute to the reconstruction of the public sphere and calls for a reframing of the common good in light of the current educational landscape (Marginson, 2016).

While some are sceptical about the possibilities of achieving common good objectives within the current HE context (Chambers and Gopaul, 2008), others take a more optimistic stance. Nixon (2016) argues that HE is uniquely placed to perform a transformative role in civic society. Similarly, Calhoun (2006) contends that universities are public in numerous senses: they provide education that equips citizens for occupations traditionally centred on public service; they advance social mobility; they produce new technologies and other innovations; they contribute to both the continuity and creativity of culture; they directly inform the public sphere and also prepare citizens to participate in it. Thus, higher education institutions have great potential to contribute to the common good.

Speaking following the EU referendum in the U.K., Welsh Government education secretary Kirsty Williams called on universities to reflect on the gulf between 'campus and community' exposed by Brexit (Williams, 2016). Williams maintains that the referendum showed that our notions of togetherness and bonds between communities are perhaps weaker than we imagined and that the task now is for universities to recapture a civic mission. Unfortunately, it is often the case that HE institutions have what Musil refers to as a 'helterskelter approach' to civic engagement where, rather than adopting a cohesive strategic approach, this area is administered largely out of sight through formal institutional representatives or via an 'add on' community engagement centre or through an existing service such as student affairs (Musil, 2003). Goddard, (2009) contends that civic engagement should not be confined to individual academics or projects; it needs to move beyond being a third or separate strand of activity for universities, instead becoming a 
guiding principle. This requires an institution-wide commitment. Others agree with Goddard's view that civic engagement needs to be defined, measured and built into the curriculum (Benson et al, 2005; LeBlanc, 2009).

This paper describes the way in which one institution has embedded a Common Good Curriculum for the benefit of both its students and the communities they serve. At GCU this means rooting civic engagement in the heart of the institutional ethos and mission and embedding student Common Good Attributes within the curriculum. In terms of provenance, the idea was formulated in response to the university's drive to meet social needs of all kinds and is reflected in the fact that GCU is the first university in Scotland to designated a Change Maker Campus by AshokaU ${ }^{1}$, acknowledging its global reputation in promoting social innovation through learning and teaching, research and community engagement. A key design element of the Common Good Curriculum development was the decision to embed common good attributes across all three stands of curricular areas: the taught curriculum and co- and extra-curricular areas. The positive impact of participation in extra-curricular activities during university on graduate employability is well known (Lau et al., 2014). Similarly, the value of students' co-curricular engagement is well recognized (Kuh, 2001). Traditionally, however, co-curricular learning is mostly voluntary in nature and is facilitated through the programming of student affairs offices/departments primarily, as it is viewed as transcending the various academic disciplines and career trajectories (Stirling and Kerr, 2015). Ahren (2009) suggests that a more systematic use of educational practices is required to assure that the relation of co-curricular participation to educational and personal development is more than merely assumed.

\footnotetext{
${ }^{1}$ AshokaU is a global network of community leaders and institutions who work collectively to make social innovation and change making the new norm in higher education and beyond.
} 


\section{Methodology}

The study adopted an Appreciative Inquiry (AI) evaluation model. This method suited the context of the research as the evaluation was designed to commence from the onset of the Common Good Curriculum development through to its conclusion over two year period. Appreciative Inquiry is an assets-based approach from the field of organisational development first advanced by Cooperrider (1987). Instead of evaluating the impact of a development at the end of its implementation, the method involves gathering data before, during and after the process of change. By applying this approach to this study the researcher has the opportunity to contribute to the development. Appreciative Inquiry is an approach to seeking what is right in an organisation in order to create a better future for it (Coghlan et al., 2014). Appreciative Inquiry applies a '5D' cycle with the following phases: Define;

Discover; Dream; Design and Deliver. Figure 1 demonstrates how the AI process was applied to the current study.

Figure. 1 The Appreciative Inquiry model applied to the Common Good Curriculum 


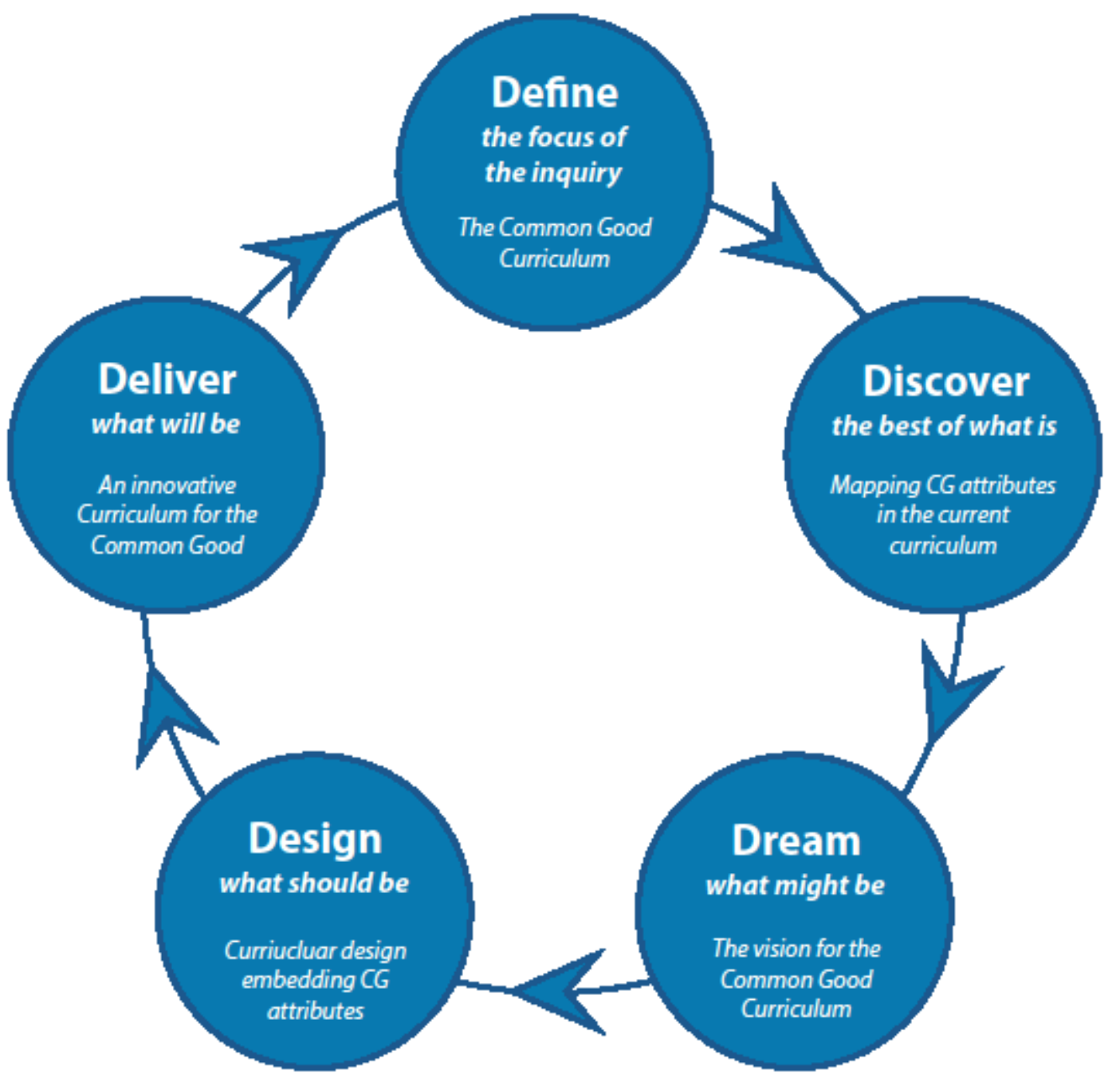

Adapted from Hammond, 2013. 
Feedback from key stakeholders was collected at each stage of the AI cycle. This included staff and student interviews, student focus groups and online student surveys. An overview of the methodological approach to each stage of the investigation is provided in Table 1.

Table 1. Research methodology by AI stage

\begin{tabular}{|c|c|c|}
\hline \multicolumn{3}{|c|}{ Research methodology by AI stage } \\
\hline AI stage & Development stage & Research methodology \\
\hline Define & The Common Good Curriculum & $\begin{array}{l}\text { - Analysis of institutional } \\
\text { documents relating to the } \\
\text { mission, vision, values and } \\
\text { supporting strategies and } \\
\text { frameworks; } \\
\text { - Interviews with members of the } \\
\text { senior executive. }\end{array}$ \\
\hline Discover & $\begin{array}{l}\text { Mapping Common Good Attributes } \\
\text { in the current curriculum }\end{array}$ & \multirow{2}{*}{$\begin{array}{l}\text { Interviews with members of the } \\
\text { senior executive; } \\
\text { - Interviews with } 15 \text { members of } \\
\text { cross-university staff responsible } \\
\text { for driving the development; } \\
\text { - Focus group with Students' } \\
\text { Association office bearers. }\end{array}$} \\
\hline Dream & $\begin{array}{l}\text { The vision for the Common Good } \\
\text { Curriculum }\end{array}$ & \\
\hline Design & $\begin{array}{l}\text { Curricular design embedding } \\
\text { Common Good attributes }\end{array}$ & $\begin{array}{l}\text { Analysis of programme maps for } \\
\text { examples of common good } \\
\text { attributes in terms of: } \\
\text { Curriculum content and design } \\
\text { (what we teach); } \\
\text { Learning and teaching activities } \\
\text { (how we teach) and } \\
\text { Assessment practices (how we } \\
\text { assess); } \\
\text { Interviews with academic staff } \\
\text { responsible for programme } \\
\text { design and delivery. }\end{array}$ \\
\hline
\end{tabular}




\begin{tabular}{|c|c|c|}
\hline Deliver & $\begin{array}{l}\text { An innovative Curriculum for the } \\
\text { Common Good }\end{array}$ & $\begin{array}{l}\text { Questions included in annual } \\
\text { GCU Student Experience } \\
\text { Survey; } \\
\text { - } \quad \text { Student focus groups; } \\
\text { - Online survey of students } \\
\text { involved in Common Good } \\
\text { Award; } \\
\text { - Focus group with Common Good } \\
\text { Award recipients; } \\
\text { - } \text { Interviews with Common Good } \\
\text { Award recipients. }\end{array}$ \\
\hline
\end{tabular}

\section{Findings}

This section presents the study's findings in terms of the respective developmental stages of the Appreciative Inquiry methodological approach: Define; Discover; Dream; Design and Deliver.

Defining the Common Good Curriculum 
An overview of the institutional mission and vision statements, key supporting strategies such as Strategy for Learning (SfL) and the Research Strategy, plus the other enabling strategies such as the Digital Strategy and Community and Public Engagement Strategy reveals that these all have the common good as key strands. In addition, the Quality Enhancement and Assurance Handbook clearly expresses the Common Good Curriculum and the Common Good Attributes and links these to the SfL. What emerges is a coherent philosophy of civic engagement which is instilled throughout university policy and processes (Votruba, 2005). The university mission, 'For the Common Good', is reinforced by the institutional vision which challenges traditional thinking about how universities should operate and the role they can play in society:

'By 2020, GCU will have a global recognition for delivering social benefit and impact through education, research and civic engagement.'

(GCU, Strategy 2020).

The Strategy for Learning (SfL) focuses on developing a distinctive approach to learning, teaching and assessment. This is based on engagement-led learning and real world problem solving, coupled with inter and multi-disciplinary curricula with opportunities for personalisation. The Common Good attributes are derived from the SfL and are defined as:

- Active and Global Citizenship - recognising and actively seeking to address global social challenges; participating in the community at a local, national or global level.

- Entrepreneurial mind-set - identifying opportunities for change; creating solutions, and putting these into practice in response to identified real world problems. 
- Responsible Leadership - developing solutions that are ethical, visionary, realistic and sustainable; exercising empathy, resilience and professionalism.

- Confidence - challenging yourself and continually learning from experience; believing you can make a positive difference by what you do.

(GCU, Strategy for Learning, 2015-2020)

Evidence that staff support the institutional mission is indeed strong. In a staff survey conducted in $2016,93 \%$ of staff $(\mathrm{N}=1,132)$ agreed with the statement: 'I believe in the University mission "for the common good" and believe it is important.'

(GCU, Staff Pulse Survey, 2016)

\section{Discovery: mapping examples of the Common Good Attributes within the curriculum}

The Common Good Curriculum was implemented by a cross-university team of academics. This was supported by an extensive mapping exercise which sought to highlight and embed all four attributes within each academic programme in three main areas:

1. Curriculum content and design: What we teach

2. Learning and teaching activities: How we teach

3. Assessment practices: How we measure what is learned

Providing this information is now a requirement for programme re/approval and forms part of the academic quality process. Members of the core group drew attention to the rationale for 
mapping the entire curriculum in terms of Common Good Attributes and sharing good practice, as one member of staff explained:

'It's about making explicit where common good attributes are taught and assessed, as well as sharing innovative approaches across programmes and academic Schools. It's also about identifying gaps, for further development.'

\section{The vision or 'dream'}

Interviews with key stakeholders revealed that the driver for the development of the Common Good Curriculum is to remain true to and to advance the institutional mission as part of core university activity, which was expressed by a member of the senior executive as follows:

'I want every student who comes to this university to have the opportunity to develop both discipline-specific skills and knowledge as well as the opportunity to be part of something bigger.'

A senior member of academic staff explained the rationale for mapping the curriculum in terms of a transformational impact:

'We anticipate that the common good curriculum not only has a transformative impact on our students but that it goes one step further - enabling students to have a positive influence on the lives of others. Thus we need to critically review our curriculum to assess to what extent we are supporting our students to gain common good attributes.' 
Rather than attempt to create a new curriculum, the development was launched via approval by the University Senate to build a framework which highlights and embeds current examples of civic engagement both within alongside the taught curriculum. When asked what the outcome of the Common Good Curriculum would be, that is, how you will know when you have achieved it, a member of the senior executive pointed to the impact on student personal development and employability as measures of success:

'Employers will recognise these attributes in our graduates and will seek out our graduates on this basis and our students will have the opportunity to contribute to something bigger within the community whether that is at a local, national or global level and will have recognition for this.'

The 'dream' for the Common Good Curriculum was clearly expressed by all participants as a worthwhile endeavour which harmonised with the institutional mission, vision and associated strategies and set the university apart within the sector. By envisioning 'what might be' by way of the vision, the design of the enhanced curriculum was next stage of focus.

\section{Design}

To drive the Common Good Curriculum development, a cross-university core group was established with membership drawn from each of the academic Schools and support departments. The work of this group was overseen by a Common Good Curriculum steering group. Student leaders were actively included in the development from the outset and formed part of the discussions at all stages. This recognises that active student engagement with the development and embedding of graduate attributes is indispensable (Hounsell, 2011). 
The core group collaborated with academic colleagues in a pilot to develop a curriculum mapping template and populated this map with examples of Common Good Attributes in terms of, 'what we teach', 'how we teach' and 'how we assess' in order to highlight examples of good practice. This also enabled the identification of opportunities for development and action plans were drawn up to address these. Thus, as part of the academic quality process, modules which have no or limited evidence that they reflect the attributes have to be amended accordingly.

In addition, each programme was required to insert new information into their student programme handbook where the attributes are defined and examples of where and how these are taught and assessed within the programme are provided. Common Good Leads were nominated for each academic School. Their role was to act as a point of contact and to promote the development to staff. The responsibility for operationalising the Common Good Curriculum, in terms of the taught curriculum however, fell to programme teams within academic Schools. Common Good web pages were also developed to describe the Common Good Curriculum and to signpost co- and extra-curricular civic engagement activities to students. Common Good Opportunities and Work Experience Hub web pages were also developed to highlight volunteering, student societies and other civic engagement opportunities at extra-curricular level. A staff and student communication strategy was implemented to raise awareness of the development.

Developments at curricular level were complemented with the introduction of the Common Good Award. The award was introduced to encourage and support students to develop the Common Good Attributes by engaging in co- and extra-curricular activities alongside their studies. The aim was to provide a mechanism through which to promote, recognize and reward the informal learning gained by participating in activities aligned to the University's Common Good mission. 


\section{Delivery: examples within the curriculum}

It is important to note that the following examples simply provide a flavour of what, where and how within the curriculum common good attributes are taught and assessed. The development is ongoing and the curriculum is still evolving. Examples of the ways in which the different Schools at GCU are embedding Common Good Attributes within the curriculum at both undergraduate and postgraduate levels include:

- The Triple 'E' spine (EEE: Employability, Enterprise and Entrepreneurship) in the Glasgow School for Business and Society. Core modules run in years 1, 2 and 3 for GSBS students. In, EEE3: Enterprise Value Challenge, students develop their understanding of how entrepreneurial activity can create both economic and social value. This occurs through experiential learning, where students either provide consultancy to a local organisation (often a social enterprise); or undertake a trading project to raise funds for a charity of their choice.

- As part of mainstreaming Common Good Attributes most programmes in the School for Health and Life Sciences, incorporate a core thread where students are required to take one Inter-professional Learning module at each level. The inter-professional framework aims to encourage confidence in team working. Throughout all of the practice education modules across the programme students are challenged to work in a diverse range of healthcare areas with a diverse range of service users and carers. Some students each year choose to undertake their elective in an emerging world nation allowing them to share their skills with other cultures and societies. While on 
practice placement students have to clinically reason and problem solve with real world service users and carers experiencing health issues.

- In the School of Engineering and the Built Environment, Integrated Engineering Studies is taught in years 1 to 3 and forms part of the Honours project in year 4 . The syllabus includes issues relevant to commercial engineering projects e.g. employment ethics, intellectual property, sustainability and environmental impact, idea generation and evaluation, design thinking, effective team-working skills and reflection on skills and confidence developed.

These examples provide evidence of how students, through learning on their programme, are enabled to develop Common Good Attributes and to build on learning from previous experiences, enhancing this experience progressively throughout their studies.

\section{Delivery: examples at co-curricular level}

To complement the evidence of examples of good practice within the curriculum, examples at co-curricular level were derived via interviews with academic staff responsible for programme design and delivery. Examples of cross-university civic engagement programmes many of which are located at School or discipline level include:

- Enactus is a global social enterprise organisation for students, academics and business leaders committed to entrepreneurial action to transform lives and shape a better more sustainable future. This initiative aligns very closely with the Common Good mission. GCU Enactus provides a platform and methodology to bring together students from across the university to work in teams to work with communities and 
individuals to create community development projects which requires students to measure the impact of the change implemented.

- GCU's Widening Access and Outreach activities provide a range of opportunities for GCU students to engage in innovative, transformative activities and projects with nursery, school children and their parents, and college students. Each year over 100 students mentor pupils and students from disadvantaged areas to help their success and future attainment. There are also opportunities to work with specific groups such as care experienced pupils/students.

- The Law Clinic is a student-led initiative that provides free and confidential legal advice and assistance to individuals within Greater Glasgow who do not qualify for legal aid and cannot afford professional legal advice. Students provide general legal advice, draft legal letters, represent clients in court and negotiate on behalf of clients in contractual disputes. All of the advice provided by law student volunteers is supervised by qualified legal practitioners.

- The Phelophepa train project involves students volunteering to work on a healthcare train in South Africa for two weeks during the summer. Optometry and Orthoptic students from the School of Health and Life Sciences join a team of full-time professionals on the train's eye clinics. During their placement, students provide eye care under supervision to a large number of patients in rural areas of South Africa.

The examples of co-curricular common good activity, taken together, complement the range of examples of where common good attributes are embedded within the taught curriculum. 
The following section provides evidence of the extent to which the third stand of activity extra-curricular common good opportunities - is currently embedded institutionally.

\section{Delivery: examples of extra-curricular activity}

To gauge the level of awareness of extra-curricular common good opportunities, in 2018 an additional question was added to annual GCU Experience Survey. Over half of undergraduate students agreed that they had had the opportunity through GCU to get involved in community engagement and/or volunteering activities ( $\mathrm{N}$ responses: 2,427; response rate: $30 \%$ ).

\section{Common Good Award}

While many universities have skills or employability awards, few of these make explicit encouraging civic engagement as a specific objective. What differentiates the Common Good Award is that it has a dual focus: students' personal development, in terms of employability and social innovation skills and the impact their engagement has had on the community they have served. This makes this award unique and encourages students to actively consider common good activities during their academic career and beyond. Enrolment is a rolling process whereby all those students who register are enrolled for all four Common Good Attribute digital badges. Those students who complete all four badges can apply for a second verification stage to be awarded the Common Good Award. This stage involves a judgement by a panel to ensure that specific Common Good projects and evidence gathered via these are appropriate and meet the criteria.

In the pilot year (2017-18), the award was limited to students in levels 3 and above. Twenty students received a total of 52 digital badges and, of those, seven students received the full award. Award recipients were recognised for community work such as volunteering as a 
special constable, running a drama class for young people with Down's syndrome, supporting people with mental health challenges, founding a sports club, working with projects to raise educational aspirations in disadvantaged communities and running a multi-cultural community canteen for adults and children. A target of 100 students receiving the full award has been set for year two of the scheme and the impact of the initiative will continue to be evaluated over time.

Student feedback on the impact of the award was gathered during the pilot year via an online survey of all students who had sought verification for digital badges $(\mathrm{N}=13)$. In addition, interviews were conducted with all award recipients $(\mathrm{N}=7)$. Feedback reveals that students pursue the award in order to have formal recognition for their common good activities that might otherwise have gone unnoticed in order to demonstrate attributes when seeking employment/further study opportunities. They appreciate the personal recognition the award confers and value the opportunity to reflect on their achievements and personal development. In addition, participants feel that the development of Common Good Attributes within their co- and extra-curricular activities has improved their employability prospects and report that the award gives them something 'extra' in a competitive job market.

Evidence from the online survey and interviews with award participants suggests that the main reason students registered for award was to increase employment opportunities. All those students who responded mentioned having either their digital badges or the award on their $\mathrm{CV}$ and some had also included these on their LinkedIn page. All respondents planned to highlight aspects of their badges/award in applications for jobs/further study and one student had already used evidence from the badges for an application for a Masters course. Students felt that possessing the badges/award provided them with an edge in a competitive job market: 
'I felt it would be a 'stand out' statement on my C.V. to increase my employability as it shows that I have proof about the skills and experience described.'

For some students, having recognition via the award had been a strategic decision based on a perception that professionals in their discipline area (psychology, social work and allied health sciences) expected students to be involved in community work. Students also reported that they appreciated gaining recognition for all the various activities they have been involved in which was said to 'really mean something personally.' Students who had completed the award also appreciated having some time to reflect on how their various co- and extracurricular activities had contributed to their personal development.

It is clear from the evidence that GCU is going to considerable efforts to put in place a mechanism to support students to develop Common Good Attributes both within the taught curriculum and in their co-and extra-curricular activities. The Common Good Curriculum develops graduates capable of tackling real-world issues and translating problem-solving ideas into action through civic engagement. Examples at curricular include core modules integrated through all levels of delivery and projects and teamwork where students are expected to help solve real-world social issues and contribute to life-transforming initiatives. Co- curricular examples engage students to co-design and co-deliver entrepreneurial projects that empower people to make real, sustainable progress for themselves and their communities. Extra-curricular common good opportunities include activities such as volunteering, mentoring, becoming a student leader or student ambassador, establishing or running a student society. In addition, students have the opportunity to gain recognition for their extra-curricular common good activity via the Common Good Award which provides 
evidence to future employers of the attributes, skills and personal development this activity has engendered.

\section{Discussion}

Evidence from this research clearly demonstrates that the curriculum can provide a mechanism through which an HE institution can bring to life its civic mission. In so doing it brings coherence to the curriculum in its entirety. Re-focusing the curriculum in this way has been recognised by others as a potential strategy for institutionalising a commitment to the public good (Benson et al, 2005). This required careful planning and was made possible in the context of the university's undertaking to serve the common good being explicit in the institutional mission, vision and values the role of which has been emphasised by Gilliland (2005). Strong institutional leadership is critical; leaders need to be very clear about the outcomes they want to produce and every element of the organization needs to be aligned to support those outcomes (Votruba, 2005).

Embedding Common Good Attributes in both the taught curriculum and in co- and extracurricular activities highlights the links between those areas of the student learning experience which are often perceived as detached (Storey, 2010). This is the transformative power of the Common Good Curriculum which ensures that students develop the attributes needed to make a positive difference to the communities they serve, in addition to acquiring the knowledge, skills and values associated with their particular professional or disciplinary areas.

Common Good Attributes are made explicit in all aspects of the learning experience. Student engagement with attributes in this way helps to form identity (Daniels and Brooker, 2014: 
74). They argue that universities need to ensure that students actively reflect on the role and cultivation of all graduate attributes in their learning, so that they 'actively participate in their identity development throughout their time at university.' This requires that students learn about the nature and role of graduate attributes that often go unrecorded; how they might be developed and evidenced. Such learning is often invisible on university academic rubrics and transcripts, and may be difficult for students to articulate and evidence to others (KensingtonMiller et al., 2018).

Findings from this study are also important in terms of the relationship between the seemingly oppositional pulls to respond to the increasing calls for universities to become more active players in their communities and regions, while at the same time responding to being pulled in global directions by the phenomena of global competition as most commonly experienced by the HE ranking systems. Hall, Bhatt and Lepore (2017) argue that the global and the local are not oppositional aspirations and that universities should aspire to being 'locally relevant and internationally significant.' The examples of curriculum innovation evident in the Common Good Curriculum illustrate ways in which Higher Education institutions can shape the curriculum to meet both the obligations of local engagement and responsibility and the global, as expressed in the 2030 UN Sustainable Development Goals (SDGs), 'all global challenges are local.' In addition, GCU is the first university to date to adopt the UN SDGs as the framework for its research strategy.

The Common Good Curriculum is a long-term development which requires ongoing monitoring and evaluation to ensure that its aims are being met. As such it's a generative process which will evolve through practice. The associated research on the efficacy of the development is likewise ongoing. Therefore it is not possible to report the full impact of the 
development as yet. The second phase of evaluation will explicitly address the views of the student body. This will address whether there is any tension between the University's sense of mission and some students' acceptance of the development for personal career-related reasons. The Common Good Award is yet to be rolled out to all students. The full impact of the award is thus not possible to measure at this stage. In addition, the full cost of the approach (economic and opportunity costs) is yet to be measured and assessed. This will require a full evaluation over the longer term.

\section{Conclusion}

This case study has demonstrated that it is possible for a university to operationalise its common good mission by focusing on the curriculum as the mechanism through which to highlight and embed common good attributes. The strategic approach aligns co- and extracurricular activity with the taught curriculum and highlights examples of civic engagement for the benefit of students and the communities they serve. In addition, students who take up common good opportunities in extra-curricular areas are formally recognised through a skills award which recognises the impact that engagement in common good activity has on the student's own personal development, employability and social innovation skills. Curriculum though must be taken in its widest sense and refers to the totality of the student learning experience, both formally within the taught curriculum and informally through co- and extracurricular activities.`This can only occur, however, when civic engagement is a guiding principle for the organisation and is made explicit in the institutional mission, values and vision. This requires a whole institution approach, strong leadership, careful planning and buy in from staff and students alike. Attributes have to be defined and communicated and the taught curriculum has to be mapped to identify examples of good practice. 
Given the increasing stratification of HE in the U.K., universities must be exemplars of how to live and work in complex democratic societies (Brew, 2015). Thus, instead of asking whether universities are currently contributing to the common good, a more apposite question is whether they are contributing to shaping the society of the future and are likely to contribute to the public good for future generations. The Common Good Curriculum is an example of how one institution has embraced this challenge. 


\section{References}

Ahren, C. S. 2009. "Disentangling the unique effects of co-curricular engagement on selfreported student learning outcomes." Unpublished dissertation. Indiana University.

Benson, L., Harkavy, I. and Hartley, M. 2005. "Integrating a Commitment to the Public Good into the Institutional Fabric.” In: Kezar, A.J., Chambers, T.C., Burkhardt and Associates (2005), Higher Education for the Public Good, Emerging Voices from a National Movement, San Francisco: Jossey-Bass.

Brew, A. 2015. “The Paradoxical University and the Public Good.” In: O. Filippakou and G. Williams (eds.) Higher Education As a Public Good, Critical Perspectives on Theory, Policy and Practice, New York: Peter Lang Publishing.

Calhoun, C. 2006. "The University and the Public Good." Thesis Eleven 84(1):7-43.

Carnoy, M., Froumin, I., Loyalka, P. K., and Tilak, J. B. G. 2014. "The concept of public goods, the state, and higher education finance: A view from the BRICs." Higher Education 68(3): 359-378.

Chambers, T. and Gopaul, B. 2008. "Decoding the Public Good of Higher Education." Journal of Higher Education Outreach and Engagement 12:4, 51-91.

Coghlan, A.T., Preskill, H. and Tzavaras Catsambas, T. 2003. "An Overview of Appreciative Inquiry in Evaluation." New Directions for Evaluation, 100, Winter 2003, Wiley Periodicals. 
Cooperrider, D.L., Whitney, D. 2005. Appreciative Inquiry: A Revolution in Change. San Francisco: Berrett-Koehler.

Cooperrider, D.L., Whitney, D. and Stavros, J.M. 2008. Appreciative inquiry handbook: for leaders of change. Brunswick, $\mathrm{OH}$ : Crown Custom Publishing, Inc.

Daniels, J., \& Brooker, J. 2014. "Student identity development in higher education: Implications for graduate attributes and work-readiness.” Educational Research 56 (1): 65 76.

Daviet, B. 2016. "Revisiting the Principle of Education as a Public Good." Education Research and Foresight, Working papers, UNESCO. Available from:

Delanty, G. 2005. 'The Sociology of the University and Higher Education: The Consequence of Globalisation." In C. Calhoun, (ed.) The Sage Handbook of Sociology. London: Sage

Dill, D. 2015. “Assuring the Public Good in Higher Education: Essential Framework Conditions and Academic Values.” In: O. Filippakou and G. Williams (eds.) Higher Education As a Public Good, Critical Perspectives on Theory, Policy and Practice. New York: Peter Lang Publishing.

Glasgow Caledonian University, Strategy 2020. Available from: https://www2.gcu.ac.uk/strategy2020/media/2020-Strategy-Brochure-OP.pdf

Glasgow Caledonian University, Strategy for Learning, 2015-2020. Available from: https://www.gcu.ac.uk/media/gcalwebv2/theuniversity/gaq/dogfiles/strategyforlearning/GCU _SfL_2015-2020_update_16.11.16.pdf 
Glasgow Caledonian University, Staff Pulse Survey. 2016. Harrogate: Capita.

Goddard, J. 2009. Reinventing the Civic University, London: NESTA.

Hall, B.L., Bhatt, N. and Lepore, W. 2017. "Curriculum, Higher Education and the Public Good.” In: F.X. Grau, J. Goddard, B. Hall, E. Hazelkorn and R. Tandon (eds.). Higher Education in the World 6. Towards a Socially Responsible University: Balancing the Global with Local. Global University Network for Innovation.

Hammond, S.A. 2013. The Thin Book of Appreciative Inquiry, Bend Or: Thin Book Publishing Co.

Hounsell, D. 2011. Graduates for the 21st Century: Integrating the Enhancement Themes, Institutional activities, The Quality Assurance Agency for Higher Education.

Kant, I. [1798] 1979. The Conflict of the Faculties, Translation and Introduction by Mary J. Gregor. New York: Abaris Books.

Kensington-Miller, B., Knewstubb, B., Longley, A. and Gilbert, A. 2018. "From invisible to SEEN: a conceptual framework for identifying, developing and evidencing unassessed graduate attributes." Higher Education Research \& Development, published online 08 June, 2018.

Lau, H.H., Hsu, H.Y., Acosta, S. and Hsu, T. 2014. "Impact of participation in extracurricular activities during college on graduate employability: an empirical study of graduates of Taiwanese business schools.” Educational Studies 40 (1): 26-47. 
Leblanc, P. 2009. Making Civic Engagement Matter to More Students: Expanding Our Reach and Improving Our Practice. In J.N. Reich (ed.).Civic Engagement, Civic Development, and Higher Education. Washington, DC.

Leibowitz, B. (ed.) 2013. Higher Education for the Public Good, Views from the South. London: Institute of Education Press.

Locatelli, R. 2018. "Education as a public and common good: Reframing the governance of education in a changing context." Education Research and Foresight, Working papers. UNESCO. Available from: http://unesdoc.unesco.org/images/0026/002616/261614e.pdf

Marginson, S. 2016. Higher Education and the Common Good. Australia: Melbourne University Publishing Ltd.

Marginson, S. 2017. Rediscovering the common good in higher education, Centre for Global Higher Education, 2 February 2017. Available from: http://www.researchcghe.org/blog/2017$\underline{\text { 02-07-rediscovering-the-common-good-in-higher-education/ }}$

Marginson, S. 2017. "The Public Dimension of Universities.” In P. Scott, J. Gallacher and G. Parry (eds.) New Languages and Landscapes of higher Education. Oxford: Oxford University Press.

Musil, C. 2003. "Educating for citizenship.” Peer Review. Spring 4-8. 
Nixon, J. 2012. Higher Education and the Public Good: Imagining the University. London: Continuum.

Preskill, H. and Tzavaras Catsambas, T. 2006. Reframing Evaluation Through Appreciative Inquiry. California: Sage Publications Inc.

Quaye, S.J. 2005. 'Let Us Speak: Including Students' Voices in the Public Good of Higher Education.” In: Kezar, A.J., Chambers, T.C., Burkhardt and Associates (eds.). Higher Education for the Public Good, Emerging Voices from a National Movement. San Francisco: Jossey-Bass.

Reich, R.B. 2018. The Common Good. New York: Knopf.

Smith, A. 1759. The Theory of Moral Sentiments. London: A. Millar, in the Strand.

Stirling, A.E. and Kerr, G.A. 2015. "Creating Meaningful Co-Curricular Experiences in Higher Education.” Journal of Education \& Social Policy 2 (6).

Storey, K.L. 2010. "Bridging the Gap: Linking Co-Curricular Activities to Student Learning Outcomes in Community College Students.” Dissertations. Paper 30. National Louis University Digital Commons.

UNESCO. 2015a. Education 2030 Incheon Declaration and Framework for Action. Paris, UNESCO. 
Votruba, J.C. 2005. "Leading the Engaged Institution.” In: A.J. Kezar, T.C. Chambers, J.C. Burkhardt and Associates (eds.) Higher Education for the Public Good, Emerging Voices from a National Movement. San Francisco: Jossey-Bass.

Williams, J. 2014. "A critical exploration of changing definitions of public good in relation to higher education." Studies in Higher Education 41(4): 619-63.

Williams, K. 2016. Universities must reflect on gulf between campus and community exposed by Brexit. Times Higher Education, 12 September, 2016.

Winter, A., Wiseman, J. and Muirhead, B. 2005. "Beyond Rhetoric, University Community Engagement in Victoria.” Eidos Institute. 